ИЗВЕСТИЯ АКАДЕМИИ НАУК ЭСТОНСКОП ССР. ТОМ 25 ХИМИЯ * ГЕОЛОГИЯ. 1976, № 4

\title{
ГЕОЛОГИЧЕСКАЯ И ПАЛИНОЛОГИЧЕСКАЯ ХАРАКТЕРИСТИКА ВЕРХНЕПЛЕЙТОЦЕНОВЫХ ОТЛОЖЕНИЙ МЕСТОНАХОЖДЕНИЯ ПЭЭДУ
}

Пээдуские межморенные органогенные отложения (левый берег р. Эльва несколько северо-западнее Отепяской возвышенности) представляют большой интерес для геологов. Впервые они были обнаружены в колодце дачи Сээсмаа и в трех близко расположенных от него скв. $1-3$. Имеется несколько радиоуглеродных датировок этих отложений: образца торфа из колодца - $20673 \pm 100$ (ТА-63, Лийва и др., 1966), образца древесины из колодца - $39180 \pm 1960$ (ТА-136, Пуннинг и др., 1967) и образца торфа из скв. $1-3-39700 \pm 850$ (ТА-254, Пуннинг, 1969). На основании этих датировок межморенные органогенные отложения были отнесены к среднему валдаю (Пуннинг и др., 1967; Вийдинг, Лыокене, 1969).

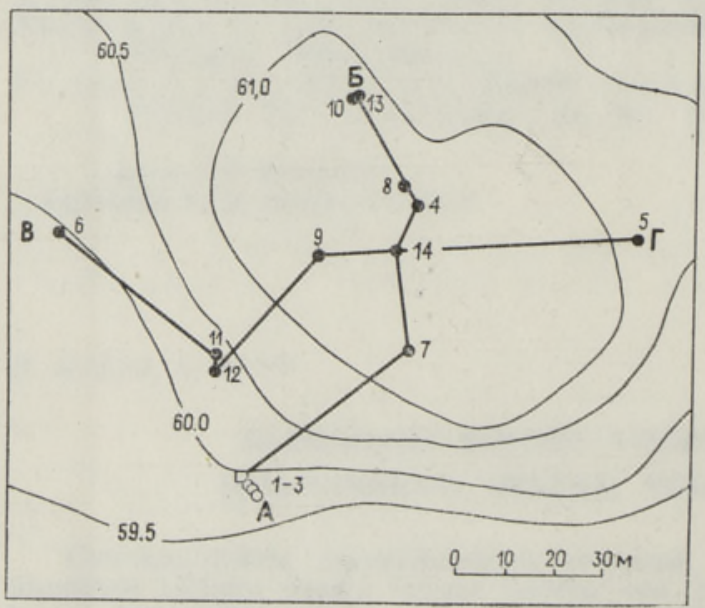

$01 \bullet 2$ व $2-600-4$

Рис. 1. Расположение точек наблюдения в местонахождении Пээду: 1 - скважины, пробуренные колонковым способом, 2 - скважины, пробуренные вибрационным способом, 3 - колодец дачи Сээсмаа, 4 - горизонтали, $A B$ и $B \Gamma-$ линии геологических разрезов.
Заложенными в местонахождении Пээду 14 буровыми скважинами (рис. 1) вскрыта типичная для Южной Эстонии красновато-бурая морена мощностью $1-3$ м (рис. 2,3), аналогичная морене из колодца дачи Сээсмаа, описанной Х. Вийдингом и Э. Лыокене (1969). Местами (скв. 8, 9, $11,12)$ на ней залегает $0,5-$ 1,0 м слой средне- или мелкозернистого коричневатого песка. Под красновато-бурой мореной во всех скважинах (за исключением скв. 12) обнаружена буровато-серая морена мощностью $0,5-2,0 \mathrm{M}$, содержание гальки в которой несколько меньше, чем в верхней. Лишь в скв. 6 обе моречы относительно богаты галечным материалом.

Третья морена - серая по цвету - залегает под буро- 

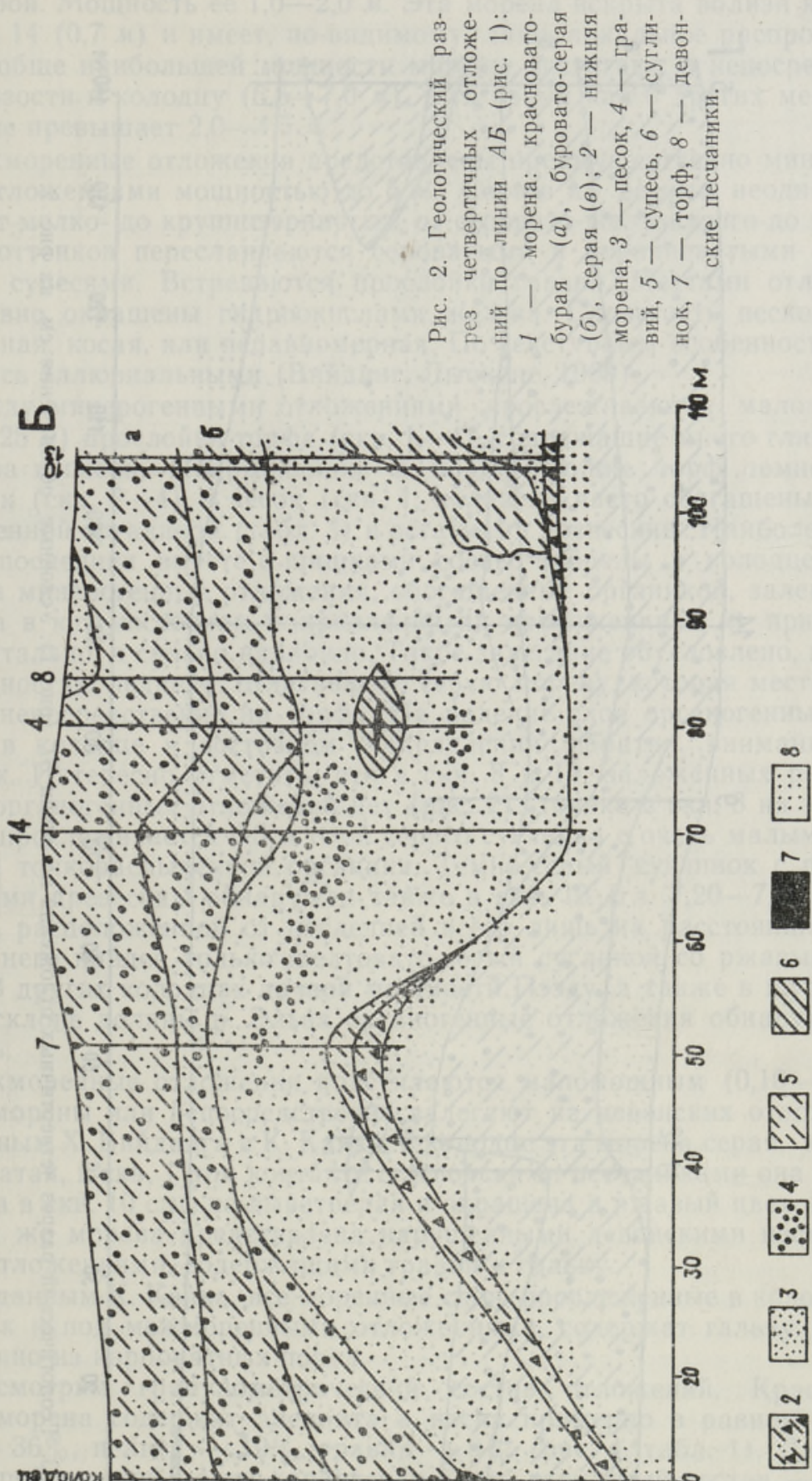

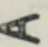
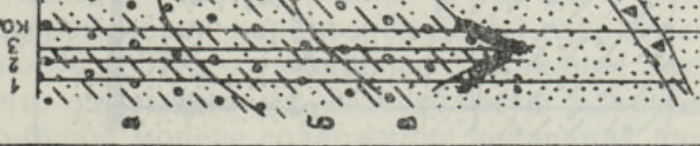

इ 영 


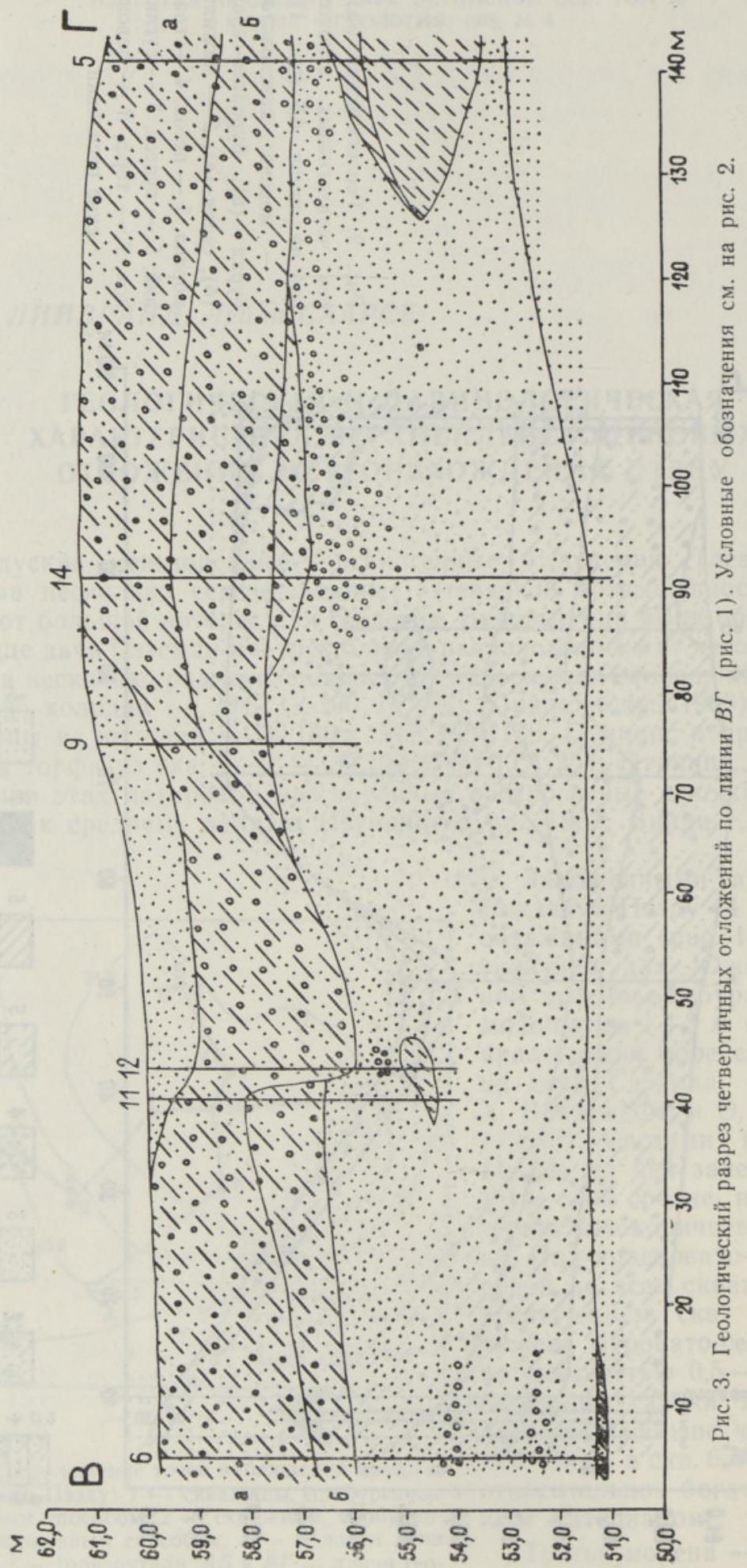


вато-серой. Мощность ее $1,0-2,0$ м. Эта морена вскрыта вблизи колодца и в скв. $14(0,7 \boldsymbol{M})$ и имеет, по-видимому, лишь локальное распространение. Вообще наибольшей мощности морены достигают в непосредственной близости к колодцу $(6,5-7,0$ м), в то время как в других местах их толща не превышает $2,0-4,5 \mathrm{M}$.

Межморенные отложения представлены преимущественно минерогенными отложениями мощностью до $5 \mu$. Состав их весьма неоднороден: пески от мелко-до крупнозернистых, от серовато-желтоватого до красноватого оттенков переслаиваются сероватыми и коричневатыми суглинками и супесями. Встречаются прослойки гравия. Местами отложения интенсивно окрашены гидроокислами железа. Слоистость песков горизонтальная, косая, или неравномерная. По текстурным ссобенностям они считались аллювиальными (Вийдинг, Лыокене, 1969).

Между минерогенными отложениями прослеживаются маломощные $(0,1-0,25 м)$ прослойки торфа (скв. $1-4)$, содержащие много глинистого вещества и песка. Покрывающие и подстилающие торф темно-серый суглинок (скв. 2-4) и песок (скв. 1, колодец) часто обогащены тонкораспыленной органикой (табл. 3) и остатками древесины. Наиболее крупные из последних вместе с шишками сосны найдены в колодце. Слои торфа и минерогенные отложения, обогащенныє органикой, залегают от колодца в юго-восточном направлении на протяжении $4 \mu$, причем не горизонтально, а сильно наклонно. Такое залегание обусловлено, видимо, деятельностью ледника, отлагавшего сепюю морену, которая местами покоится непосредственно на торфе. На падение слоя органогенных отложений в колодше в восточном направлении обратил внимание еще К. Каяк. Интересно отметить, что в скв. 8 и 14, заложенных рядом со скв. 4, органогенных отложений нет (рис. 2); только в скв. 8 на этом же уровне прослеживается 0,3 м слой серого суглинка с очень малым содержанием тонкораспыленной органики. Темно-серый суглинок с редкими остатками древесины обнаружен также в скв. 10 (гл. 7,20-7,60 ), а в скв. 13, расположенной от последней всего лишь на расстоянии метра, вместо него найден только желтовато-серый суглинок со ржавыми пятнами. В других колодцах дачной местности Пээду, а также в шурфах на левом склоне долины р. Эльва органогенные отложения обнаружить не удалось.

Межморенные отложения подстилаются маломощным $(0,10-0,60$ м) слоем морены или непосредственно залегают на девонских отложениях. По данным Х. Вийдинга и К. Каяка, в колодце эта морена серая, местами желтоватая, в скв. 1 при контакте с девонскими песчаниками она красноватая, а в скв. 10 сильно выветрелая и окрашена в ржавый цвет. В скв. 6 и 7 эта же морена представлена нарушенными девонскими пестроцветными отложениями, содержащими гравий и гальку.

По данным К. Каяка, все моренные слои, прослеженные в колодце как над, так и под межморенными отложениями, содержат гальку преимущественно из карбонатных пород.

Рассмотрим гранулометрический состав отложений. Красноватобурая морена содержит алеврита и песка примерно в равном количестве $-36 \%$, пелита $-19 \%$, гравия $-9 \%$ (рис. 4 , табл. 1). Для буровато-серой и серой морен характерен более глинистый состав - пелита соответственно 30 и $37 \%$, суммарное содержание алеврита и пелита более $75 \%$, что указывает на значительную однородность этих морен. В красновато-бурой морене содержание последних двух фракций составляет менее $50-55 \%$. Несмотря на то что гранулометрический состав морен разный, он все же не может служить критерием для их стратиграфнческого подразделения (Балтрунас и др., 1974), так как его нельзя 


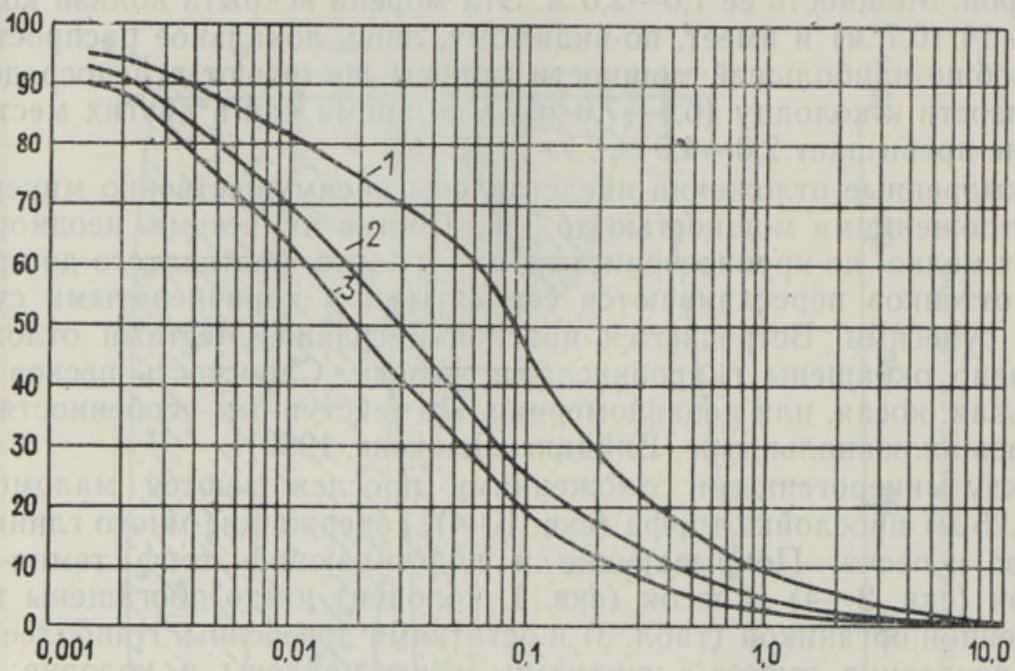

Рис. 4. Суммарные гранулометрические кривые морен Пээду: 1 - красновато-бурая, 2 - буровато-серая, 3 - серая.

Таблица 1

Гранулометрический состав морен

\begin{tabular}{|c|c|c|c|c|c|}
\hline \multirow{2}{*}{ Морена } & \multirow{2}{*}{ 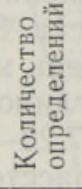 } & \multicolumn{4}{|c|}{ Содержание фракций, вес. \% } \\
\hline & & $>1 M M$ & $1-0,1$ мм & $0,1-0,01$ м.м & $<0,01$ s.M \\
\hline $\begin{array}{l}\text { Красновато- } \\
\text { бурая }\end{array}$ & 4 & $\frac{9,2}{6,2-12,3}$ & $\frac{36,1}{29,0-41,6}$ & $\frac{35,9}{33,9-39,0}$ & $\frac{18,8}{13,2-23,0}$ \\
\hline $\begin{array}{l}\text { Буровато- } \\
\text { серая }\end{array}$ & 5 & $\frac{5.4}{3,4-7,4}$ & $\frac{18,7}{15,5-20,9}$ & $\frac{45,8}{44,2-48,1}$ & $\frac{30,1}{27,3-36,0}$ \\
\hline Серая & 1 & 3,4 & 15,2 & 47,1 & 37,2 \\
\hline
\end{tabular}

П р и м е ч н и е: в числителе - среднее значение, в знаменателе - пределы изменения значения фракций.

рассматривать вне связи с физико-механическими показателями (табл. 2).

Как видно из табл. 2, более низкие значения естественной влажности, коэффициента пористости, числа пластичности свойственны красноватобурой морене и более высокие - буровато-серой и серой. Величины же объемного веса, напротив, понижены у первой, но повышены у второй и третьей. Поскольку гидрогеологические условия можно считать сходными для всех трех морен, причина такого несоответствия кроется, видимо, в высыхании поверхностной красновато-бурой морены в ходе постседиментационных процессов.

О большой плотности красновато-бурой морены свидетельствуют твердая и полутвердая консистенция и сравнительно низкие значения влажности на пределе ее текучести и пластичности. Из-за более глинистого состава пределы пластичности буровато-серой и серой морен на $1-3 \%$ выше, чем красновато-бурой. 
Физические свойства морен

Таблица 2

\begin{tabular}{|c|c|c|c|c|c|c|}
\hline Морена & 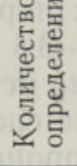 & $\begin{array}{l}\text { Объемный } \\
\text { вес, } 2 / \text { M }^{3}\end{array}$ & $\begin{array}{c}\text { Объемный } \\
\text { вес скелета, } \\
2 / C M^{3}\end{array}$ & $\begin{array}{l}\text { Естествен- } \\
\text { ная влаж- } \\
\text { ность, \% }\end{array}$ & $\begin{array}{c}\text { Пористость, } \\
\%\end{array}$ & $\begin{array}{c}\text { Коэффи- } \\
\text { циент пори- } \\
\text { стости }\end{array}$ \\
\hline $\begin{array}{l}\text { Красно- } \\
\text { вато-бурая }\end{array}$ & 6 & $\frac{2,27}{2,20-2,33}$ & $\frac{2,02}{1,93-2,08}$ & $\frac{12,1}{10,9-14,8}$ & $\frac{25,1}{22,9-26,2}$ & $\frac{0,34}{0,30-0,40}$ \\
\hline $\begin{array}{l}\text { Бурова- } \\
\text { то-серая }\end{array}$ & 8 & $\frac{2,22}{2,16-2,31}$ & $\frac{1,95}{1,87-2,03}$ & $\frac{14,7}{12,4-16,7}$ & $\frac{28.2}{24,8-30,8}$ & $\frac{0.38}{0,33-0,44}$ \\
\hline Серая & 1 & 2,19 & 1,90 & 15,5 & 29,5 & 0,42 \\
\hline
\end{tabular}

Аналогичные закономерные различия наблюдаются также в механических свойствах, т. е. красновато-бурая морена по сравнению с буроватосерой и серой имеет повышенную сопротивляемость сдвигу (угол внутреннего трения $35^{\circ}$, сцепление $0,08 \kappa 2 / \mathrm{cm}^{2}$ ) н пониженную сжимаемость (коэффициент сжимаемости $0,008 \mathrm{~cm}^{2} / \kappa 2$ ).

Степень однородности моренных слоев, вычисленная на основе данных объемного веса и пористости с использованием $\tau$-критерия, или одностороннего критерия Грэббса (Солодухин, 1975), одинакова у красновато-бурой и буровато-серой морен. Для серой морены такой расчет не проводился ввиду недостаточного количества определений.

Состав спорово-пыльцевых спектров межморенных отложений Пээду очень сложный. Здесь прослеживается два комплекса пыльцы и спор межледниковых растений. Первый из них (скв. 1, колодец), характеризуемый большим количеством пыльщы дуба (до $35 \%$ ), лещины (10$50 \%$ ), ольхи (до $15 \%$ ) и вяза (до $5 \%$ ) (рис. 5), имеет некоторое сходство со спорово-пыльцевыми спектрами микулинского межледниковья.

Второй комплекс (скв. 2-4, колодец) отличается от первого преобладанием пыльцы хвойных - ели до $80 \%$ и сосны до $60 \%$. Количество пыльцы ольхи в несколько раз превышает количество пыльцы лещины. Среди широколиственных пород доминирует пыльца граба (до 15\%). Пыльцы вяза, дуба и липы не более $3 \%$. Спорадически, но довольно часто встречается пыльца пихты в количестве до $5 \%$. Определена пыльца Picea sec. Omorica и падуба (рис. 5, 6). Все это напоминает спектры лихвинского межледниковья. Однако наличие межледниковой пыльцы в отложениях не всегда может служить верным признаком существования межледниковых климатических условий, так как пыльца и споры могут быть переотложенными. Иногда межледниковые отложения включены отторженцами в толщу отложений ледниковых эпох. Все это принималось в расчет при изучении спорово-пыльцевых спектров разреза Пээду.

Максимум пыльцы дуба, обнаруженный в отложениях скв. 1 (рис. 5), сопровождается большим количеством пыльцы трав $(30-45 \%)$, в составе которой в обогащенных органикой песках на гл. 7,00-7,40 м преобладает пыльца злаковых и осоковых, а в серых и коричневых суглинках на гл. 7,40-7,60 $м$ - пыльца полыней и маревых. Последние, как первые обитатели еще несформировавшихся почв, характерны для ледниковых эпох. Особенно широкого распространения они достигли в перигляцихльных условиях на только что освобожденных ото льда территориях. Поэтому наличие большого количества пыльцы полыней и маревых в суглинках скв. 1 говорит в пользу существования приледниковых условий во время накопления здесь этих отложений. Найденная же в суглинках, а также в 
покрывающих их песках пыльца термофильных пород - дуба, вяза, лещины, ольхи - по всей вероятности, переотложена из нижней части микулинских межледниковых отложений.

Сравнительно много пыльцы таких же термофильных пород присутствует и в желтовато-бурых песках колодца (на гл. 7,9-8,4 м), расположенного в 4 м северо-западнее скв. 1. Однако в отличие от последней здесь найдена пыльца ели (до $26 \%$ ) и обнаружено обилие спор зеленых мхов (60-90\% от общего количества). Столь большой процент спор, с одной стороны, явно отрицает распространение лесной растительности во время образования этих песков, а с другой - вновь подтверждает вывод о том, что пыльца древовидных пород переотложена из микулинских отложений.

Второй комплекс пыльцы и спор обнаружен в слое торфа и в обогащенных органикой темно-серых суглинках, супесях и песках (рис. 5,6$)$. В торфе ель и сосна содержатся либо в равных количествах $(40-50 \%)$ (скв. 2-4), либо преобладает ель $(40-60 \%$, скв. 3$)$ или сосна $(60 \%$, колодец). Ольхи до $30 \%$, лещины до $4 \%$. Обнаружены граб и пихта. Наибольшее количество термофильных пород найдено в покрывающих или подстилающих торф темно-серых суглинках, а также в песках на гл. 7,7 $\mu$ в колодце. Несмотря на постепенное увеличение или уменьшение количества пыльцы термофильных пород, эти два максимума скорее всего говорят не о двух климатических оптимумах, а о наличии переотложенной пыльцы в отложениях. На это указывает и отсутствие закономерных изменений пыльцевых зон, характерных для межледниковий.

Желтоватые, от мелко- до разнозернистых, пески скв. 4 на гл. 6,606,80 м (рис. 6) содержат наряду с пыльцой термофильных пород много пыльцы карликовой березы $(10-40 \%)$. Такое же количество ее обнаружено в слое темно-серого суглинка на гл. $6,20-6,25$ м. Однако в залегающем выше торфяном слое на гл. 5,80-6,10 $м$ пыльца Betula nana L. уже не была обнаружена, хотя содержание пыльцы термофильных пород здесь минимальное. Это говорит о том, что слой торфа представляет собой отторженцевую часть межледниковых отложений, включенных в состав минерогенных. Смешанные спорово-пыльцевые спектры последних свидетельствуют о наличии пыльцы, переотложенной из межледниковых отложений. По-видимому, только пыльца карликовой березы и трав, а также споры, особенно зеленых мхов, являются свидетелями той растительности, которая произрастала в районе Пээду во время образсвания изученных отложений.

Итак, палинологический анализ показал, что спорово-пыльцевые спектры межморенных отложений Пээду очень изменчивы, а подчас смешаны по своему составу, что не позволяет выделить характерные для межледниковий пыльцевые зоны. Это, по всей вероятности, объясняется переотложением, которое в таких масштабах не могло произойти в межледниковое время. Оно скорее всего произошло в перигляциальных условиях, когда территория Әстонии освободилась ото льда, но еще не была покрыта лесной растительностью. Видимо, о местной, синхронной с осадконакоплением перигляциальной растительности говорит пыльца карликовой березы, найденная вместе с пыльцой термофильных пород на гл. $6,20-6,25$ и $6,60-6,80 \mu$ в скв. 4 , а также наличие пыльцы трав. В составе последней в скв. 1 (гл. 7,4-7,6 м) и скв. 4 (гл. 6,7 м) обнаружено много пыльцы полыней и маревых, которые более характерны для холодо- и сухолюбивой растительности, распространяющейся после отступания ледникового покрова. Выше по разрезам пыльцевые зерна полыней и маревых встречаются реже. Вместо них кульминирует пыльца осоковых, которой особенно много в скв. 4 на гл. $5,40-5,60$ м, и присутствует пыльца 
\begin{tabular}{c|c} 
Quercus \\
10 & 20 \\
10 & $20 \%$
\end{tabular}

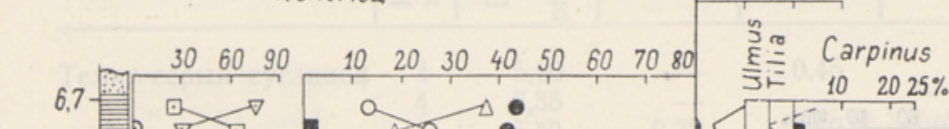

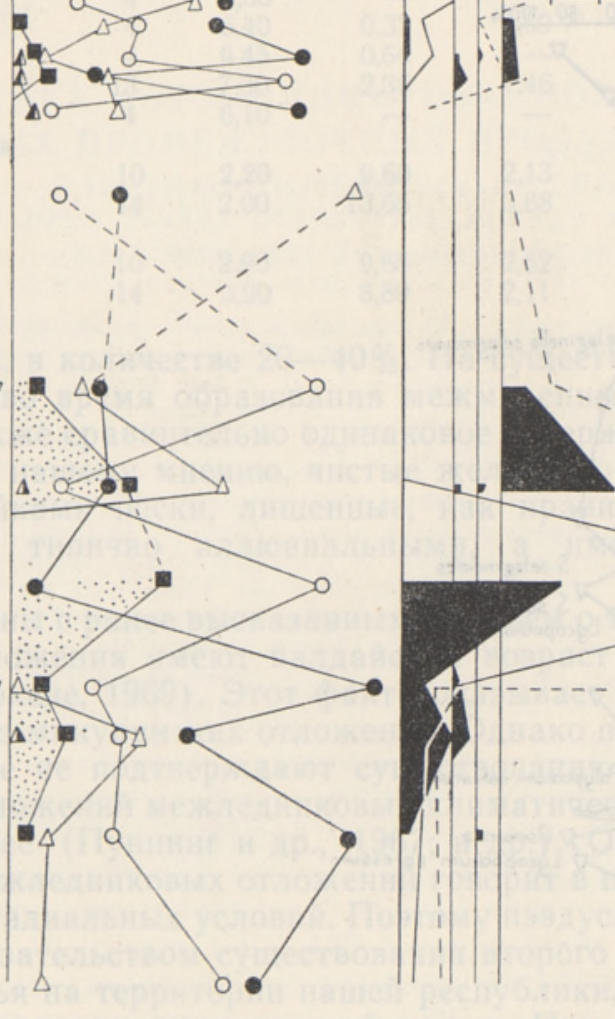

$C_{k b .2}$
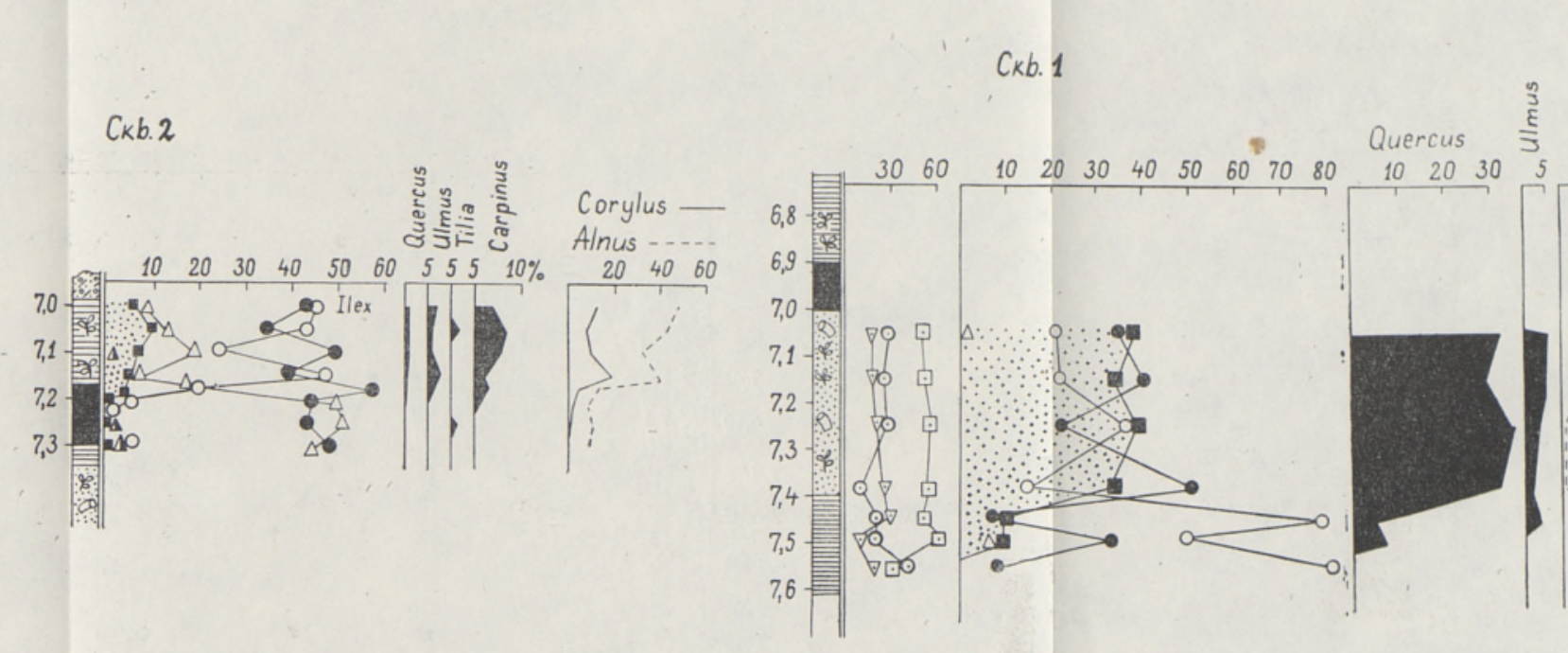

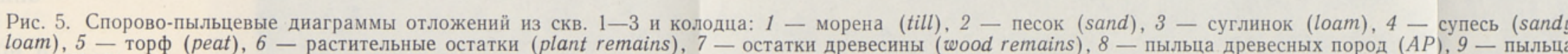

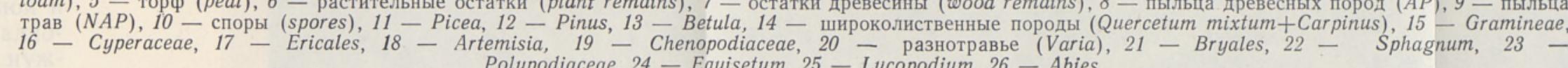


Betula humilis -1
Betula nana -2 -
B. sec. Albae-3
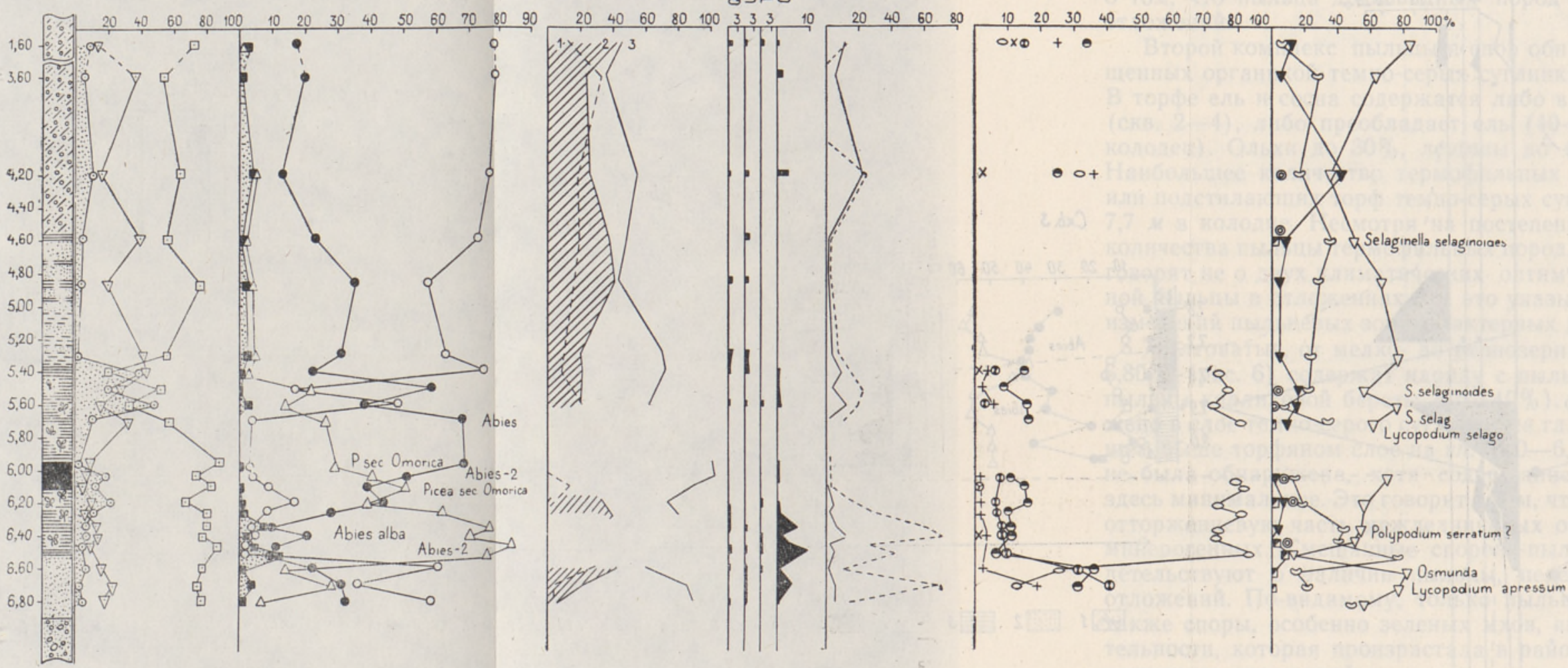

Рис. 6. Спорово-пыльцевая диаграмма четвертичных отложений скв. 4 в Пээду. Условные обозначения см. на рис. 5 . 
хблица 3

Орган.

веще-

ство

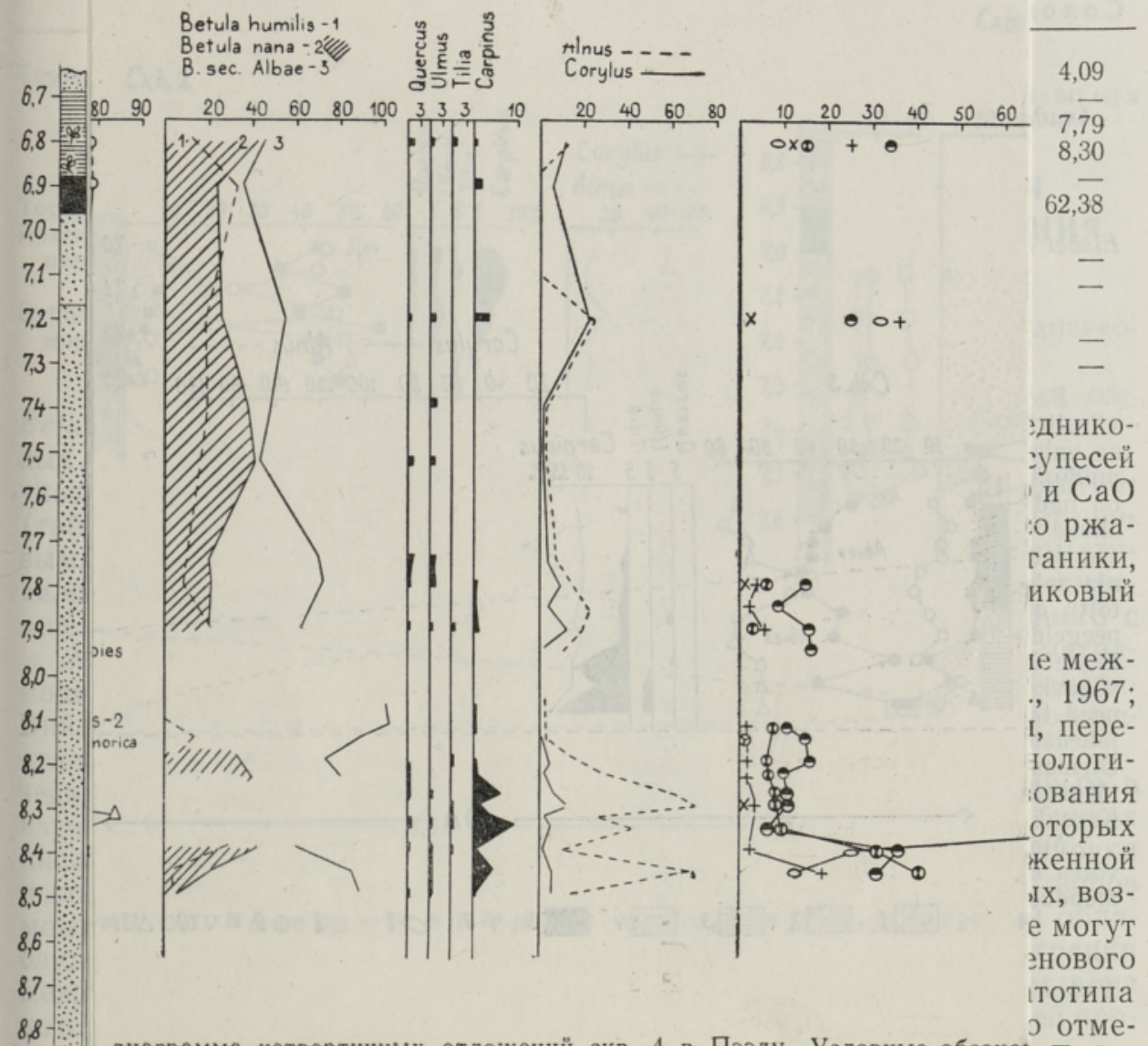

диаграмма четвертичных отложений скв. 4 в Пээду. Условные обознат Лийв-

дной и

радио-

:т нуж-

реотло-

ая обра-

еского и

Совета

В еличкевич $Ф$., Лий в ранд $Э$. 1976. Новые даттые о флоре и растительности разреза Карукюла в Эстонии. Изв. АН ЭССР, Хим. Геол., 25, № 3.

В и йдинг Х., Л ыокен е Э. 1969. Средневалдайские межстадиальные отложения в Пээду (Юго-Восточная Эстония). Изв. АН ЭССР, Хим. Геол., 18, № 3. 
покрываг

щины, оЈ

микулинс

Сравн

ствует и

ложенно

здесь наї

мхов (60

одной стс

время об

о том, ч1

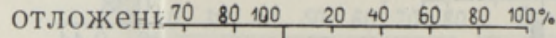

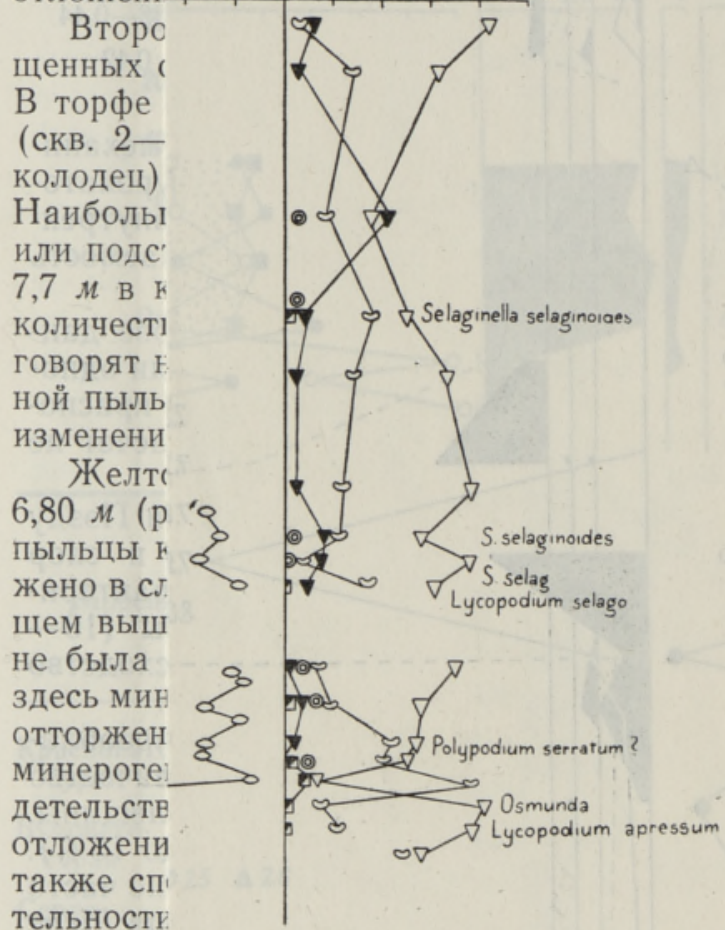

изученны

Итак,

спектры ґения см. на рис. 5 .

шаны по

межледнг

переотлог

ледников

виях, ког,

покрыта :

конакопл

ковой бег

$6,20-6,2$

ве послед

пыльцы г

сухолюби

никового покрова. Выше по разрезам пыльцевые зерна полыней и маревых встречаются реже. Вместо них кульминирует пыльца осоковых, которой особенно много в скв. 4 на гл. 5,40-5,60 м, и присутствует пыльца 
Содержание органического вещества, $\mathrm{CaO}$ и $\mathrm{MgO}$ в отложениях местонахождения Пээду, \%

\begin{tabular}{|c|c|c|c|c|c|c|c|}
\hline Характер отложений & 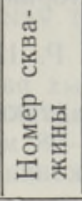 & 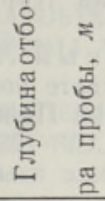 & $\mathrm{CaO}$ & $\mathrm{MgO}$ & $\mathrm{CO}_{2}$ & $\mathrm{CaCO}_{3}$ & $\begin{array}{c}\text { Орган. } \\
\text { веще- } \\
\text { ство }\end{array}$ \\
\hline Темно-серый суглинок & 4 & 5,80 & - & 0,45 & - & 一 & 4,09 \\
\hline$"$ & $\begin{array}{l}4 \\
4\end{array}$ & $\begin{array}{l}6,35 \\
6,40\end{array}$ & $0, \overline{32}$ & $0, \overline{69}$ & 0,25 & $0, \overline{57}$ & $7, \overline{79}$ \\
\hline$"$ & 4 & 6,45 & 0,66 & - & & 1,17 & 8,30 \\
\hline & 13 & 7,30 & 2,30 & 1,46 & 3,47 & 4,1 & \\
\hline $\begin{array}{l}\text { Tорф } \\
\text { Красновато-бурая }\end{array}$ & 4 & 6,10 & - & - & - & - & 62,38 \\
\hline морена & 10 & 2,20 & 9,60 & 2,13 & 10,27 & 17,1 & - \\
\hline Буровато-серая & & & & & & & \\
\hline $\begin{array}{c}\text { морена } \\
\text {, }\end{array}$ & $\begin{array}{l}10 \\
14\end{array}$ & $\begin{array}{l}2,90 \\
3,90\end{array}$ & $\begin{array}{l}9,68 \\
8,89\end{array}$ & $\begin{array}{l}2,62 \\
2,11\end{array}$ & $\begin{array}{r}10,78 \\
9,78\end{array}$ & $\begin{array}{l}17,3 \\
15,9\end{array}$ & 二 \\
\hline
\end{tabular}

Betula nana L. в количестве $20-40 \%$. На существование водно-ледниковых условий во время образования межморенных суглинков и супесей указывает также сравнительно одинаковое содержание в них $\mathrm{MgO}$ и $\mathrm{CaO}$ (табл. 3). По нашему мнению, чистые желтовато-бурые, иногда со ржавыми прослойками пески, лишенные, как правило, видимой органики, являются не типично аллювиальными, а имеют водно-ледниковый генезис.

Мы согласны с ранее высказанным мнением о том, что пээдуские межморенные отложения имеют валдайский возраст (Пуннинг и др., 1967; Вийдинг, Лыокене, 1969). Этот факт доказывает наличие пыльцы, переотложенной из микулинских отложений. Однако полученные палинологические данные не подтверждают существования во время образования изученных отложений межледниковых климатических условий, о которых писалось ранее (Пуннинг и др., 1967; и др.). Обилие переотложенной пыльцы из межледниковых отложений говорит в пользу ледниковых, возможно, межстадиальных условий. Поэтому пээдуские отложения не могут служить доказательством существования второго верхнеплейстоценового межледниковья на территории нашей республики, в качестве стратотипа которого приводился карукюлаский разрез. При этом необходимо отметить, что последний оказался лихвинского возраста (Величкевич, Лийвранд, 1976).

Пээдуские межморенные отложения, которые подстилаются одной и покрываются тремя разновидностями валдайских морен, имеют радиоуглеродную датировку порядка 39 тыс. лет. Однако этот возраст нуждается в уточнении, т. к. он может быть искажен из-за наличия переотложенного материала.

\section{Л ИТЕРА Т У Р А}

Балтруна с В., Г айг ал а с А., К уч а с В., М о т з а Г. 1974. Статистическая обработка на электронно-вычислительных машинах данных гранулометрического и минералогического анализов морен плейстоцена Южной Литвы. Тр. УГ Совета Министров ЛитССР, Лит. НИГРИ, вып, 27. Вильнюс.

Вели чкевич Ф., Лий в р а нд Э. 1976. Новые данные о флоре и растительности разреза Карукюла в Эстонии. Изв. АН ӘССР, Хим. Геол., 25, № 3.

Вийдинг Х., Л ыокене Э. 1969. Средневалдайские межстадиальные отложения в Пээду (Юго-Восточная Эстония). Изв. АН ЭССР, Хим. Геол., 18, № 3. 
Л и й в а А., Иль в ес Э., Пунни и г Я.-М. 1966. Список радиоуглеродных датировок Института зоологии и ботаники АН ЭССР. Изв. АН ЭССР, Бнология, 15, № 1.

Пунннинг Я.-М. 1969. Применение радиоуглеродного метода для изучения истории покровного оледенения в верхнем плейстоцене и эволюции древнебалтийских водоемов в раннем и среднем голоцене на территории Прибалтики. Автореф. канд. дис. Таллин.

Пунннинг Я.-М., Р аука с А. В., С еребрянный Л. Р. 1967. Геохронология последнего оледенения Русской равнины в свете новых радиоуглеродных датировок ископаемых озерно-болотных отложений Прибалтики. Материалы II симпо зиума по истории озер Северо-Запада СССР (23-28 мая 1967). Минск.

С олоду х и М. А. 1975. Инженерно-геологические изыскания для промышленного и гражданского строительства. М.

Институт геологии

Академии наук Эстонской ССР

Поступила в редакцию

3/VI 1975

\author{
Elsbet LIIVRAND, Leili SAARSE
}

\title{
PEEDU LEIUKOHA ULEMPLEISTOTSEENI SETETE GEOLOOGILINE JA PALUNOLOOGILINE ISELOOMUSTUS
}

Pecdu moreenidevahelised setted koosnevad peamiselt kollakatest, paiguti roosteviirulistest kallak- ja pōimkihilistest liivadest, milles leidub saviliiva, liivsavi ja peene kruusa vahekihte. Kohati (kaevus ja puuraukudes $1-4$ ) leidub ōhukesi, rikkalikult turvast ja puidujäänuseid sisaldavaid kihte (joon. 1,2,3). Setete ehitus on väga muutlik. Enamasti on nad kaetud kolme eriilmelise valdai moreeniga, nende all on kas devoni liivakivi vōi ōhuke valdai moreeni kiht. Palünoloogilise analüüsi pōhjal sisaldavad moreenidevahelised setted ümbersettinud öietolmu ja eoseid, mis pärinevad kahe eri vanusega jäävaheaja setetest. Tōenäoliselt on ümber settinud algul mikuulini, seejärel lihvini setted. Seetôttu on kujunenud väga keeruka koostise ja muutliku ilmega öietolmuspektrid, mis ei peegelda enam nendele jäävaheaegadele iseloomulikku taimestiku arengut (joon. 5,6 ) Peale ümbersettinud öietolmu on leitud ka periglatsiaalsele taimkattele iseloomulike vaevakaskede, rohttaimede, pujude, maltsade ja roheliste sammalde õietolmu ning eoseid: need taimed võisid Eesti maa-alal kasvada uuritud setete moodustumise ajal. Suhteliselt jahedale settimiskeskkonnale viitab ka $\mathrm{MgO}$ ja $\mathrm{CaO}$ ligikaudselt vorrdne sisaldus setetes. Olemasolevate andmete pōhjal on uurıtud setted kujunenud pärast mikuulini jäävaheaega, tõenäoliselt valdai jäätumise ajal esmenud interstadiaali vältel. Peedu interstadiaalsete ja Karuküla tüüpiliste jäävaheajasetete kōrvutamine pole palünoloogiliselt õigustatud.

Moreenide lōimis (tab. 1, joon. 4) ja ehitusgeoloogilised omadused (tab. 2) mōnevôrra erinevad, kuid need erinevused ei seostu setete vanusega, vaid peegeldavad neride moodustumise lokaalseid iseärasusi.

\section{Elsbet LIIVRAND, Leili SAARSE}

\section{GEOLOGICAL AND PALYNOLOGICAL INVESTIGATION OF UPPER PLEISTOCENE INTERMORAINIC DEPOSITS AT PEEDU}

Intermorainic deposits at Peedu are represented by horizontally laminated yellowish sand containing loam and thin gravel layers. In some sequences, peat and loam layers, rich in plant and wood remains, have also been discovered. The intermorainic deposits are overlain by three different Valdaian tills and underlain by Devonian sandstone or one Valdaian till (Figs 1, 2, 3). According to the palynological investigation, they contain rebedded pollen grains of different-aged interglacial rigin. Probably at first the Mikulian sediments were redeposited and after that the Likhvian ones. As a result of redeposition, a complicated pollen spectrum was formed (Figs 5, 6). Besides rebedded interglacial pollen grains, the deposits also contain pollen of Betula nana, Artemisia, Chenopodiaceae and other herbs. It is possible that the periglacial vegetation spread on Estonian territory during the formation of intermorainic deposits at Peedu. The deposits investigated were probably formed after the Mikulino interglacial, during the Valdaian interstadial. Interstadial intermorainic deposits at Peedu do not correlate palynologically with the typical interglacial deposits at Karuküla, in spite of their similar radiocarbon dates.

The grain size composition of tills at Peedu is not uniform (Table 1, Fig. 4). The geotechnical properties of three tills (Table 2) are represented by high density, low compressibility and great shearing resistance. 